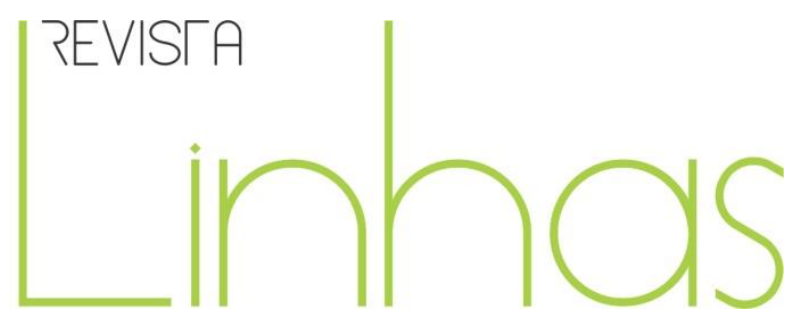

\title{
Estudo do processo gráfico educativo e estético de crianças na periferia urbana de Marabá/PA
}

\section{Resumo}

Abrange os campos da educação, filosofia da arte e sociologia, com reflexão dirigida à educação em ambiente periférico. Tem com objetivo estudar o processo educativo estético da criança que de algum modo envolve-se com a violência no âmbito doméstico, escolar e/ou da periferia urbana na cidade de Marabá. Para tanto, reúnem-se autores de bases epistemológicas distintas como Hokheimer e Adorno (1985), Schiller (2002), Brandão (2007) e Lowenfeld (1977), Arheim (1980), Gombrich (1986), cuja intenção é propor, a partir da metodologia rizomática, uma consistência do conjunto das linhas de conhecimentos diversos, delineados para explicar a experiência de se mover por territórios de conhecimentos em incessantes descobertas; assim, cria-se uma rede de significações com base em um sistema acêntrico, envolvendo diferentes áreas epistemológicas, já que o problema é complexo e multidimensional. Resulta uma rede de conhecimentos, tais como: valorização da criança de periferia como produtora de uma cultura mediada pelo processo educativo nessa territorialidade; conceitos diversos de criança e infância; visibilização da arte infantil a partir de reflexão dos impactos empreendidos pelo nó de violência que a periferia condiciona; conhecimento do repertório cultural a partir da relação da criança com a ambiência e comunidade em que vive.

Palavras-chave: Criança de Periferia. Processo Educativo na Periferia. Violência Infantil.

\author{
Alexandre Silva dos Santos Filho \\ Universidade Federal do Sul e \\ Sudeste do Pará - UNIFESSPA - \\ Marabá/PA - Brasil \\ alixandresantos@gmail.com
}

\footnotetext{
Para citar este artigo:

DOS SANTOS FILHO, Alexandre Silva. Estudo do processo gráfico educativo e estético de crianças na periferia urbana de Marabá/PA. Revista Linhas. Florianópolis, v. 19, n. 40, p. 360-393, maio/ago. 2018.
} 


\title{
Study of educational process mediated children aesthetic in symbolic violence, social and physical in urban periphery of Marabá/PA
}

\begin{abstract}
It covers the fields of education, philosophy of art and sociology, with reflection directed at education in a peripheral environment. It has the objective of studying the aesthetic educational process of the child that in some way was involved with violence in the domestic, school and / or urban periphery in the city of Marabá. In order to do so, authors of different epistemological bases such as Hokheimer and Adorno (1985), Schiller (2002), Brandão (2007) and Lowenfeld (1977), Arheim (1980), Gombrich (1986). The aim of this work is to propose from the rhizomatic methodology a consistency of the various lines of knowledge, designed to explain the experience of moving through territories of knowledge in unceasing discoveries, a network of meanings is created based on an accentric system involving Different epistemological areas, since the problem is complex and multidimensional. It results in a network of knowledge, such as: valuing the child of the periphery as producer of a culture mediated by the educational process in this territoriality; Concepts of children and childhood; The visibility of children's art based on the impact of the impact of violence on the periphery; Knowledge of the cultural repertoire based on the child's relationship with the environment and community in which he lives.
\end{abstract}

Keywords: Child from Periphery. Educational Process in the Periphery. Child Violence. 


\section{Introdução}

A criança participa e interage com a imagem do seu meio. Na fronteira do pensamento ela sente, age e torna-se inseparável da íntima imaginação que está em sua mente e faz relação com as coisas fora dela - a sensibilidade perceptual converte-se na parte mais importante do processo de conhecer o mundo exterior. Isso é um ótimo pretexto para se observar como ocorre o diálogo estético da criança com o desabrochar da sua capacidade criadora. Consolida-se, então, a partir da expressão gráfica, o envolvimento da arte infantil subordinada a um modo de criar coisas. Logo, tudo que envolve a corporeidade infantil reflete-se na ação criadora de um fazer silencioso, mas realizada dialogicamente entre o eu interior e a exterioridade experimentada pela vida da criança.

O processo gráfico educativo e estético da criança na periferia urbana da cidade de Marabá envolve um mundo conspirado pela violência no âmbito doméstico, escolar e/ou da comunidade urbana em que ela vive. Trata-se, pois, de situações encontradas na vida de meninos e meninas mediados pelo constrangimento de violências recebidas por meio de ações simbólicas, sociais e físicas, cujas concepções afetam o pensamento infantil. Implica fundamentalmente olhar a criança e sua infância a partir do lugar em que habitam e da sua família.

Para tal, é central a compreensão desse processo de objetivação, posto que influi na comunicação da criança com o mundo concreto e real. Percebe-se que, de algum modo, a invasão da expressividade artística, interferência da onda de violência simbólica e a intromissão na forma estética no ato de criação é uma consequência pressuposta na ordem do progresso na Amazônia oriental paraense. Este que fora instituído, historicamente, a partir do projeto governamentista brasileiro, e que promoveu levas de invasões e ocupações da territorialidade Amazônica entre 1960 e 1990 (impulsionados com a criação de novos municípios), conforme análise de Becker (2005). O que leva à reflexão de que tais dinâmicas socioculturais e territoriais não conduzem a sustentação de politicas públicas com vista à promoção da cidadania de periferia, com efetiva democratização. Em vez disso, dissolve-se o sujeito periférico em desvalorização sócio/econômico/cultural e as famílias na periferia urbana de Marabá são penalizadas, ocasionando alienação e controle de acesso ao conhecimento e aos bens culturais, 
mantendo um estado de espoliação e exploração, com o intuito de perpetuação de uma minoria explorada.

Mediante o exposto é que se suscita a base epistemológica deste estudo. Logo, elenca-se na primeira premissa desta compreensão o modo como o esquematismo kantiano ${ }^{1}$ influi, ainda hoje, no pensamento dos adultos e, por conseguinte, no da criança. Nesse sentido, o processo educativo estético que, de alguma forma, está na condição subordinada da dominação política e que a sobrevivência da infância na periferia implica em relações sociais de vários níveis irão influir na mudança de hábitos perceptivos. Sobretudo, se há uma condição imposta por meio da estrutura econômica nas periferias urbanas que pode determinar o modo de vida da criança e da sua família, persistindo a transformação da consciência, dos valores humanos e das formas de comportamento.

Em decorrência da dinâmica do conhecimento potencial criador infantil e da valorização da imaginação plástica, aliada à poética visual das crianças, busca-se a compreensão da arte na educação e na vida delas. Norteia-se, para este fim, a segunda premissa: o gesto gráfico da criança como discurso visual reflete o repertório de situações vividas e subjetivas a partir da comunidade em que vive na periferia.

Nessa perspectiva, é que se reúnem autores como Hokheimer e Adorno (1985), Schiller (2002), Brandão (2007), Lowenfeld (1977), Arheim (1980), Gombrich (1986) dentre outros, a fim de estabelecer uma dimensão plural em que o estudo interdisciplinar possa suscitar a metodologia rizomática como consistência do conjunto das linhas de conhecimentos que se organizam e propõem a experiência de se mover por territórios de conhecimentos em incessantes descobertas, a fim de criar uma rede de significações com base em um sistema acêntrico, envolvendo diferentes áreas epistemológicas, já que o problema é complexo e multidimensional.

A partir do processo do esquematismo kantiano é que se propõe um estudo crítico a respeito da construção que envolve o fazer artístico e estético infantil, mediante o processo educativo que perfila a ideia de infância na periferia urbana de Marabá, sob a

\footnotetext{
${ }^{1}$ Esquematismo kantino é uma referência dado por Theodor Adorno na obra Teoria Estética por exigência de compreender a forma como as pessoas usam suas percepções para entender e conceber o mundo, bem como para se comunicarem. E como diz Santos-Filho (2016) é um mecanismo intelectual, é a capacidade de uma pessoa em relação a percepção com os conceitos formados na sua subjetividade em que as experiências são transformadas em modos de pensamentos padronizados.
} 
interferência condicional da violência praticada nessa territorialidade. Demonstra-se, assim, a principal relevância desta pesquisa, e se refere aos artefatos com os quais a criança tem maior proximidade como os brinquedos, o desenho, a pintura, as construções etc., uma vez que estes integram o universo da criação e fruição e são significativos para a criança contemporânea, já que se incorporam no processo educativo naturalmente.

Apontam-se resultados mediante a uma rede de conhecimentos oriundos da realidade cotidiana, enfatizando-se alguns aspectos inerentes à concepção voltada ao poder simbólico, tais como: a valorização da criança de periferia como produtora de uma cultura mediada pelo processo educativo na territorialidade Amazônica; a revisão dos conceitos diversos de criança e infância, baseados nos significados da estrutura econômica dominante na vida dessa localidade; bem como a visibilização da arte infantil a partir de reflexão dos impactos empreendidos pelo nó de violência (simbólica, social e física), que na periferia se condiciona a uma frágil expressão que não encontra um significado de arte; e, por fim, o conhecimento do repertório cultural, a partir da relação da criança com a ambiência e comunidade em que vive, é material suficientemente constitutivo da sua consciência estética, artística e comunicacional.

Toma-se, por conseguinte, com base na produção cultural da infância, o ponto de vista sobre racionalidade adulta, capaz de promover relações sociais prevalecentes e influir na concepção de mundo da criança. Resulta daí uma complexidade histórico-social sob diferentes dimensões - cultural, ideológica, psicológica, estética e pedagógica -, constituindo-se em particularidades de numerosos estudos no campo das ciências sociais e humanas.

Para o debate, neste momento da pesquisa, traz-se primeiramente o significado de ser criança na periferia Amazônica e seus desdobramentos, vivências mediante os aspectos da dinâmica sociocultural existente na territorialidade histórica e o encontro da criança com os tons da violência, sejam de caráter físico, social, cultural e/ou simbólico.

Embora ainda se tenha a percepção da criança envolvida com os aspectos pertinentes aos contextos sócio-históricos e culturais, o segundo momento é para dizer que, mediante o convívio com a família e com a comunidade, a criança ressignifica as representações e construções simbólicas de sua intencionalidade na expressão criadora 
com a arte, já que isso alivia sua frustação e a despoja das opressões que recebe do meio onde vive. E é assim que se discute o repertório cultural e social por meio da ambiência da criança.

Este ainda é caracterizado pelos esquemas gráficos que sustentam a realidade imediata por meio do estado de graus progressivos de apropriação dos objetos do mundo exterior e a representação deles como signos gráficos. O tema família foi definido nesse contexto e é explorado no presente texto, como sendo o aspecto preponderante, característico do envolvimento e produção espontânea de elaboração da criança, não como réplicas da realidade, mas como uma invenção mental equivalente à representação gráfica que indica a percepção original dos signos configuracionais no processo de aprendizagem do uso dos signos verbais relativos ao que geralmente ela pensa: "a criança aprende a formar seus signos configuracionais principalmente por meio da observação do comportamento-de-fazer-signos-configuracionais de outras pessoas, por observar inicialmente que outras pessoas fazem desenhos [...]" (WILSON; WILSON, 1997, p. 61).

Além de tudo isso, há um terceiro momento dado a dois aspectos desse conhecimento: a criança no contexto da dinâmica sociocultural Amazônica e a arte que emerge nesse ambiente cotidiano. Portanto, vislumbram-se as questões político-sociais referentes à territorialidade regional e ao trânsito migratório de famílias, muito fluentes na contemporaneidade e que influem na consciência de mundo da criança sobre a sua produção gráfica e do processo criativo.

\section{Vivências: criança, infância e violência}

A criatividade artística é um processo de esquematismo que permeia a vida das crianças cotidianamente. É distintiva e tem a propriedade de indicar habilidades, destrezas físicas, resistência aos processos de inculcação das meninas e dos meninos. Por meio deste artifício, representar o mundo é qualificá-lo como artefatos imaginários vivos, que implicam expressões particulares de um fazer constante. Poder-se-ia dizer assim, enquanto a criança brinca, pensa e conta histórias, produzindo e selecionando coisas, interpretando e reformando objetos existentes no mundo objetivo e que não servem mais aos adultos. 
A arte infantil, nessa dimensão, desempenha um papel potencial e vital na expressão pessoal das crianças, já que reúne diversos elementos de sua experiência e, com isso, forma significados e é um rico momento pedagógico, uma vez que tem como base a experiência estética. Além disso, admite-se que os objetos pertencentes à sensibilidade estética da criança possam se converter em algo muito importante em sua vida, promovendo momentos extraordinários na consolidação do seu processo criador e educativo.

É por essa compreensão que Lowenfeld e Brittain (1970) admitem existir uma estreita correlação da sensibilidade infantil com as coisas no mundo, implicando aprendizagem e mobilizando esquemas estéticos capazes de subornar a realidade constrangida pela sociedade que impões valores padronizados como hegemônicos. Daí se diz que, quanto maior a oportunidade da criança se envolver com a manipulação das coisas da realidade concreta (real) mais terá possibilidades de perceber o mundo cultural dos artefatos construídos pela humanidade. Essa concepção preside outra subjacente, formulada do seguinte modo: a maioria dos brinquedos das crianças parecem ser indispensáveis ao desenvolvimento delas, no entanto, é preciso observar que muitas crianças

[...] precisam de uma corrente contínua de estímulo. Sem esse incentivo, a vida, para elas, perderia todo o sabor. Tornar-se-iam insensíveis à riqueza do ambiente que as rodeasse. Sua busca contínua de novos estímulos nada mais seria que uma fuga diante da sua incapacidade para lidar com elas próprias, com sua imaginação, com seu mundo. É esta mesma possibilidade de fuga que proporcionamos a uma criança inquieta, quando the oferecemos mais coisas com que brincar. (LOWENFELD, 1977, p. 10)

O brincar assume, desde então, o primeiro ato de esquematização intelectual da criança. Por esse motivo, define-se o brinquedo como "coisa" que ela adiciona no seu brincar livre e espontâneo, que passa, assim, a ter uma importância na constituição dos novos estímulos na brincadeira. Sendo o brinquedo o desdobramento fundamental para a construção de novos esquemas e presente na manifestação processual da ludicidade, é que ele passa a ser um instrumento posto ao serviço da brincadeira, da recreação, do 
lazer e do jogo, caracterizado por um potencial estético mediante a forma que se estrutura na mente de criança, um modo de cultivar a autonomia infantil.

Se a criança que brinca alcança desígnios definidos por sua liberdade, há também aquelas que são usurpadas na territorialidade Amazônica por sua condição de ser criança - infante -, subordinada ao processo de transformação da infância na interculturalidade regional. Todavia, se a interação de famílias em migração com as famílias nativas promove novos rumos da infância é porque existem aspectos culturais que favorecem haver criança sem infância. E, nesse feitio significante, ser criança é desafio contingente de viver a infância na Amazônia.

Estes contornos diferentes na história dos habitantes dessa amazonidade permitem observar que a criança vem sendo alvo dos mesmos desígnios de séculos. A reflexão, não obstante, sublinha que deve existir um tratamento que despoja a infância da criança, sua forma adultificada, sobretudo porque esta posição esquematizada aponta para a instrumentalização da criança pela própria família, para o ambiente do trabalho. Mas, é ao mesmo tempo no seio da própria família (que a acolhe), que a criança é também constrangida - pelo medo, pela violência, pelo modo arbitrário de educar em casa etc.

A violência contra a criança, no contexto sociocultural e histórico da cidade de Marabá, está presente há muito tempo, pois ela permeia o cotidiano, principalmente, da marginalidade das famílias que estão nas zonas periféricas da cidade. Neste caso, ressaltam-se as comunidades constituídas pelas invasões de terras no espaço urbano. Além do mais, há um leque de violências que se apresenta à realidade subjacente, seja ela simbólica, física, sexual e psicológica, visíveis na maioria dos casos, mas invisíveis nos modos de existências infantis. Entretanto, quando se oportuniza à criança expressar por meio do desenho espontâneo sua própria realidade, ela emerge através da visualidade gráfica representada pela criança com reflexo da mentalidade afetada do menino ou da menina, golpeando o esquematismo infantil. Falando nisso, mais amplamente, pode-se perceber a esse respeito que há um índice de violência infantil (e adulta) em todas as camadas sociais, constituindo-se parte de um esquematismo afetado, uma verdadeira e maligna devassa dos direitos humanos da sociedade local. 
A onda de violência tem como consequência fatores que irão refletir na sociabilização das crianças, sendo elemento presente no cotidiano familiar e escolar, além de central ideia no esquematismo que envolvem os repertórios culturais e estéticos infantis. Por outro lado, a família, enquanto estrutura de base para a criança não é mais o seio protetor; passa a ser uma ameaça para a infância. Destacam-se vários casos de crianças que foram abusadas, deixadas na rua, abandonadas por parentes, maltratadas por seus genitores ou responsáveis. Diante disso, percebe-se que a criança quando cresce num ambiente desta modalidade, desenvolve-se numa ausência de infância (HEYWOOD, 2004).

Para ampliar a reflexão conceitual e simbólica sobre o âmbito do esquema cultural e estético que envolve a violência com as crianças na periferia em Marabá, é que se torna necessário desvelar a precária situação educativa que impregna-se nas famílias. Há a constatação de que, ainda hoje, muitas famílias veem seus filhos como sendo sua propriedade. Motivo este que incide em estabelecer com naturalidade a disciplina no seio familiar com as violentas palmadas (e até mesmo espancamentos) - herança cultural que vem prevalecendo ao longo da história na região -, tornando-se assim, a própria família, ameaçadora da infância local. Essa história vai se repetindo, geração após geração. Os filhos agem da mesma forma, legitima-se o ato disciplinar da violência pelo legado sociocultural como a maneira legal e normal de tratamento dado às crianças da periferia urbana, uma vez que foi assim que pais e mães (no passado) foram condicionados à educação familiar. Logo, aceito como cultural e vivo em muitas comunidades na contemporaneidade urbana em Marabá.

Com a implementação e divulgação do Estatuto da Criança e do Adolescente - ECA, e as instalações dos mecanismos de proteção e defesa da criança em Marabá, muitas das violências contra a criança foram refreadas. Porém, há ainda casos que persistem, pois a violência infantil tem sido aceita pela sociedade como algo estetizante e, o constrangimento sócio-educativo na infância, natural. No refluxo desses matizes, a violência tem sua causa, além da premissa da herança cultural das famílias, há marcas da pistolagem, conflitos agrários e personalidades autoritárias; há também aquelas promovidas como consequências da ocupação ao longo da história da cidade marabaense. Isso tudo reflete a diversidade dos discursos de interesses por parte da 
posse de terras, ocasionando também homofobia, preconceito étnico, xenofobia, poderio simbólico dado pelo domínio do capital econômico etc.

O fato de a criança chegar à idade adulta quando é escolarizada - aprende a ler e escrever -, faz com que se perceba que o mundo do adulto se diferencia do mundo da criança. O esquematismo da escolarização, para Postman (1999), representa etapas que devem ser alcançadas pela criança para chegar ao mundo do adulto. Quer dizer que a criança só irá fazer parte da idade adulta quando adquirir a habilidade da leitura e da escrita. Por conseguinte, a criança deveria ter uma vida de preparação para esse ingresso na vida das pessoas adultas.

Muitos tabus sociais e confidencias dos adultos já foram, em seu tempo, elementos para condicionar a separação entre o mundo adulto e o mundo da criança. Hoje em dia não há tantos segredos que separem as crianças do acesso à maturidade adulta. As reservas adultas referentes a sexo, moda, dinheiro, drogas, vícios, moralidades etc., que eram esquemas adultos velados às crianças, atualmente são difundidos em revistas, jornais, telenovelas, propagandas e até mesmo em desenhos animados. Aproximando, assim, a criança dos conteúdos sigilosos do mundo adulto. Para tanto, isso

significa mais do que dizer que a "inocência" da infância está perdida, uma frase que tende a indicar unicamente uma diminuição do encanto da infância. Com a revelação rápida e igualitária de todo o conteúdo do mundo do adulto pela mídia elétrica, várias consequências profundas se fizeram notar. (POSTMAN, 1999, p. 99, grifo do autor)

Ora, o esquematismo à estética do mundo infantil abre portas e emperra outras; a inocência perdida inaugura outros desígnios para o contexto da infância na sociedade mundial. Pode-se dizer que em Marabá as crianças estão sendo bombardeadas o tempo todo com os segredos dos adultos e estes incluem outros temas como violência, criminalidade, prostituição, abuso sexual, tráfico de drogas, torturas, conflitos de terras etc.

A partir dessa constatação há uma separação entre a família e a criança na sociedade contemporânea local, que pode ser figurada aqui pelo esquematismo voltado aos instrumentos tecnológicos (TV, computador, celular, tablet, PSP®, X-BoX®, 
PlayStation $\circledast$, além das redes sociais - Internet), como sendo os mediadores que distanciam os pais das suas crianças ou as crianças dos pais. Nesse sentido, pode-se até dizer que as crianças têm pouca convivência com a família, pois vários aspectos promovem esse afastamento social e de afetividade, posto que a interação da criança com os meios tecnológicos, com as influências das diversas mídias que se apresentam como discurso dos adultos, influenciam a mentalidade infantil a pensarem como adultos, inclusive quando se referem a atos criminosos na comunidade.

Parece que isso renova o esquematismo usurpador no intelecto infantil e naturaliza o conteúdo social violento a cada dia de interação estética com a violência. Vai embaçando a infância em meio às rápidas informações que recebe da comunidade local e comunicacional. A figura 01, abaixo, é um exemplo. Tem como princípio o esquema narrativo da história em quadrinhos, próprio de uma criança (11 anos). Esse conteúdo temporaliza a ação da violência, condena à morte, alguém indesejado. Conflitos das relações adultas passam a ser os conflitos que envolvem a mente da criança também.

Figura 01 - desenho com base na narrativa da história em quadrinhos e conteúdo de violência produzida no mundo adulto.

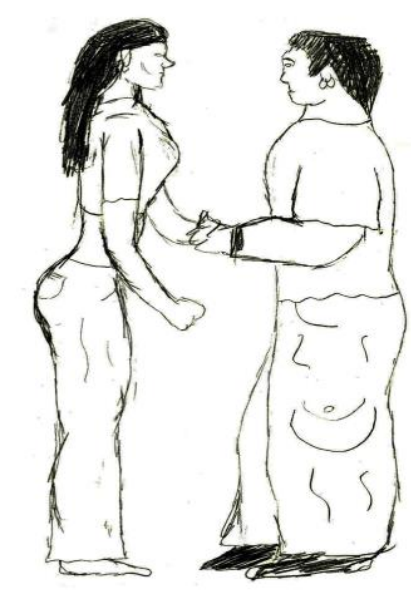

Encontro 1

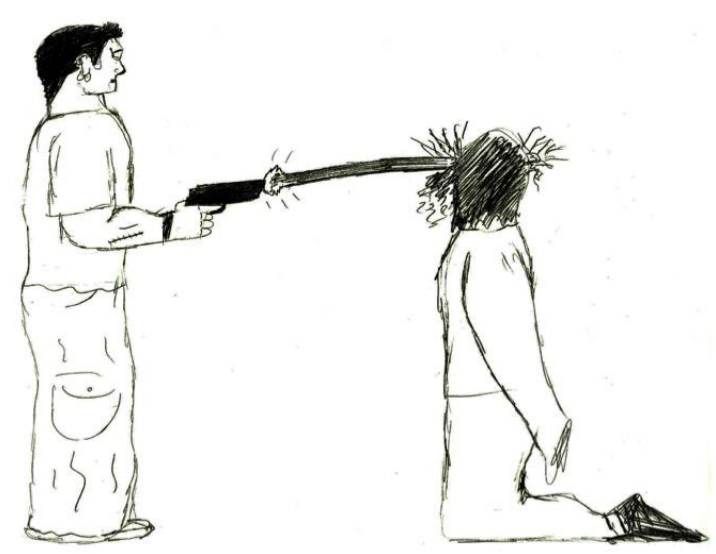

Encontro 2

Fonte: Laboratório de Expressão Plástica do Projeto de Pesquisa Racionalidade Estética: estudo do processo de criação artística de criança no município de Marabá/UNIFESSPA. 
Outro exemplo pode ser visualizado na figura 02. Em Marabá, a ideia de infância se estratifica, dada pela onda do progresso econômico que vem alargando as portas dos investimentos por meio do modismo, do comércio e, ao mesmo tempo, dos conflitos sociais. Nesse sentido, os esquemas vão-se constituindo numa ordem que se desdobra em diversos embates, referentes aos ocupantes de terras na região, ocasionados por massacres de grupos defensores da ecologia e do meio ambiente; por invasores de terras ao longo das rodovias ou fazendas improdutivas que foram griladas no período da ditadura militar; ou ainda, invasões urbanas em prédios abandonados e terrenos em áreas desvalorizadas da cidade. Todavia, também se fazem notar famílias migrantes que são atraídas pela exploração de riquezas e/ou promessas de trabalho como forma de melhoria de vida. Por isso, a figura 02, traduz no esquema gráfico essa relação e não é à toa que tudo isso possa se revelar na expressão gráfica de uma criança.

Figura 02 - A criança (11 anos) mostra o repertório das situações dado pelos conflitos no mundo cotidiano.

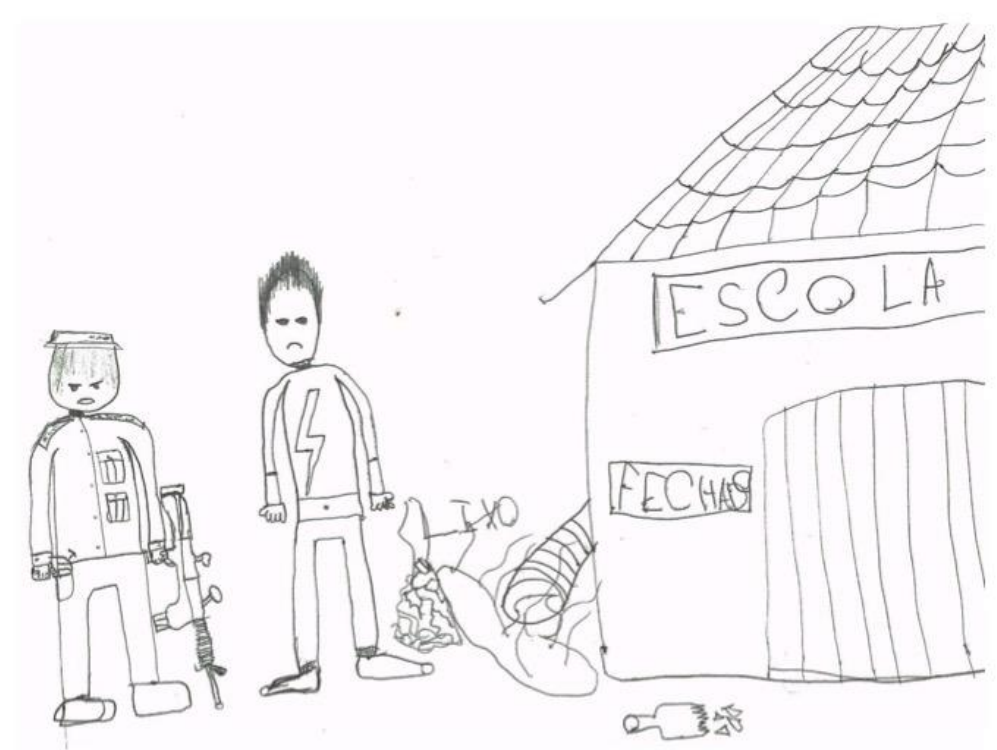

Fonte: Laboratório de Expressão Plástica do Projeto de Pesquisa Racionalidade Estética: estudo do processo de criação artística de criança no município de Marabá/UNIFESSPA.

Percebe-se claramente que o mundo adulto adentra pouco a pouco no mundo cotidiano das crianças e estas se apropriam de esquemas sociais e não escapam dos repertórios desse campo, já que as crianças também fazem parte das situações citadas, refletindo assim no modo de vida dos ocupantes com os seus familiares. As crianças e os 
adultos vivem em meio a esses contextos psicológicos e sociais que pouco se diferem em ambos os mundos. Elas observam o tempo todo o repertório social e cultural oriundo dos modos de vida dos adultos, que posteriormente passa a compor subjetivamente como sendo o seu próprio repertório imagético e imaginário, refletindo em suas expressões gráficas e artísticas.

Destaca-se, de antemão, que o processo de criação artística está relacionado organicamente ao estético, cuja percepção faz a diferença quando há provas evidentes de que tocar, ver, ouvir, cheirar e saborear absorvem a participação ativa da criança em uma dada experiência criadora - artística e estética -, desdobrando-se em uma racionalidade que permite expressar o pensamento mais fecundo e inseparável da produção material e estética na infância. Quer dizer, a racionalidade em questão é uma categoria estética, influi e exige desígnio artístico, tanto em si quanto em função de uma significação pois, como esquematismo da infância, deixa vestígio quando há elaboração da criança em face do material que emprega e na sua expressividade imaginária do produto e do ato criador - eis que é assim que a forma estética se representa.

Ademais, é um modo muito pessoal de a criança resolver a organização, a distribuição, a composição dos elementos sensíveis que estruturam e comandam a objetividade racional (esquemática) do seu objeto artístico. Nesse sentido, a racionalidade estética participa do processo de conceber os elementos artísticos da expressividade da criança por meio de uma racionalidade calcada em uma objetivação da renúncia de ingredientes supérfluos, mas que trata da emancipação do ato criador, na condição de opressão e submissão.

A forma estética, então, irá representar a racionalidade do pensamento da criança, resultante da totalidade da transformação de um ato criador dado por meio do conteúdo da linguagem, da percepção e da compreensão (ADORNO, 2006). Essa dimensão enfrenta, na sociedade contemporânea, o contraponto que advém do fato de ser a produção criadora da criança - o brinquedo e a arte infantil -, reflexo da constituição do selo da mercadoria racionalizada que recalca a expressão infantil. Nessa condição, estão também os atos violentos dos adultos mediante o comando dos impulsos dados pela pressão imediata das suas investidas assinaladas por uma profunda hostilidade aos sentimentos e esquematismo da racionalidade na criança, o que resulta em opressão. 
Destaca-se, ainda que, mediante essa construção, há uma série de acontecimentos simbólicos que influem na forma como a criança expressa sua arte, baseada em estudos científicos, caracterizada pela construção convincente de que a estrutura irracional do pensamento e da ação criativa infantil tem como referência o modelo de receptividade voltado ao prazer de percepções previamente esquematizadas. Conforme demonstra Freitas (2003), a racionalidade estética sublinha o conceito da manifestação da autoexpressão. Vista sob o contexto da infância, ela significa a forma da ludicidade e da arte que menos tem sido explorada quando se trata do significado da criatividade artística das crianças, cujo potencial emancipatório se viabiliza na construção crítica da sociedade e cultura produzida aos moldes dos adultos.

Nesse estudo, enfatizam-se dois aspectos por meio dos quais os produtos culturais impõem-se perante a racionalidade estética de natureza infantil e que rastreiam o processo educativo na cultura de periferia: i) a indução aos estereótipos, resultantes da intensiva propagação de produtos recém-surgidos e oferecidos pela sociedade de consumo aos habitantes da periferia; ii) e a adesão "voluntária" que proporciona a aceitação de tudo que circula na periferia urbana como se fosse algo natural - como no caso da violência simbólica e física, da propaganda de produtos (de uma elite dominante) que trafega conteúdos e engessa a reflexão crítica. Além do mais, é preciso também observar que existe a possibilidade da emancipação dos esquemas impostos pela indústria cultural e que atingem as crianças na periferia urbana, já que há um forte fator de se criar esquemas por meio de uma concepção que promove a recepção de uma "falsa estética". Nesse sentido, pergunta-se: que experiência criadora é essa mediada por uma racionalidade que impregna socialmente esquemas impostos no modo de influir a concepção educativa da criança de periferia, condicionando todo o processo de criação e autonomia da criança que tende a se subordinar aos valores adultos, então, quais implicações isso envolve?

Para pensar sobre a questão é indispensável a compreensão sobre a dimensão em que se organiza a experiência estética, uma vez que a expressividade artística da criança está determinada pelo ato de criação como processo educativo e tem sua significação afetada por um primeiro acorde com o objeto estético, que, por conseguinte, também está sob tensão e isso é essencial para lançar mão à primeira reflexão sobre a práxis 
artística e criadora da criança a partir do seu modo de "fazer" e de "brincar". Ao se defender a proposição de que a experiência radical com a forma estética no mundo objetivo em que a criança vive é mediada pelas contradições da sociedade atual, estabelece-se um confronto entre a identidade subjetiva e a objetiva da criança, a partir da premissa de que é a experiência com a forma estética que faz a aproximação entre arte, estética e formas do brincar na infância da periferia urbana em Marabá.

Por outro lado, é condição fundamental buscar a autonomia infantil em meio às condições heterônomas dadas pela capacidade de esquematização da própria criança e superação da violência sofrida. Dessa maneira, estabelece-se uma forma de possibilitar a ampliação da percepção infantil ao se transformar a condição de expressão e segurança física da criança mediante a constituição de "esquemas", operados de modo criativo pela imaginação na relação de posse da criança, produzindo significação no seu comportamento lúdico.

Diga-se de passagem que, ao se problematizar a forma estética da produção artística da criança de periferia urbana, afetada por violências, mediante o processo educativo estético da cidade de Marabá, engendra-se pela categoria que trata da racionalidade estética vinculada ao esquematismo e à violência infantil. Ou seja, a reflexão sobre as influências do esquematismo à estética, sob a concepção kantiana, se desenrola por meio dos textos críticos de Schiller (2002) e Adorno (2006), sob um ponto de vista fundamental: a criança que sofreu constrangimento na infância é resultado do poder simbólico do adulto que se reveste com a ordem dos postulados fundamentais da “civilização” (HORKHEIMER, 2002). Busca-se, portanto, compreender em que medida o processo do esquematismo do entendimento tem como tarefa fundamental a participação no processo educativo da criatividade da criança e na sua expressividade.

Seguindo esta compreensão, o conceito de criatividade adquire outro entendimento quando analisado por meio da ótica da dimensão estética. A criatividade passa, então, a ser uma objetivação da imaginação e tem como um dos seus esteios a forma estética mediante o processo educativo. A criatividade corresponde não só à epistemologia, mas também à moral, à educação e à estética, tornando-se um processo de realização da gramática visual, a qual estrutura o percurso do pensamento sobre a 
realidade e consolida os aspectos fundantes de uma comunicabilidade que se institui verbal e não verbal.

Enfim, a arte infantil das crianças na periferia urbana em Marabá é constitutiva de sua vivência familiar e comunitária, primordialmente para o ajuste e afinidades no processo de mudanças perceptuais de ser e estar no mundo. Assim, a transformação gráfica e visual, do ponto de vista da sua interação e afinidade com os materiais propícios às suas necessidades é a motivação central do seu deslumbramento do mundo que captura: o social e o cultural.

\section{Arte infantil na periferia urbana em Marabá}

O modo de criação artística da criança envolve o aspecto relacionado aos repertórios culturais e sociais que vivenciam no seu convívio familiar e com a comunidade na periferia urbana. Daí, é fundamental cultivar a expressão gráfica infantil, visto que significa um campo de representações, de construções simbólicas, pois assegura a sua intencionalidade de expressão e um dos meios de aliviar algumas frustrações que oprimem a criança.

Para Lowenfeld e Brittan (1970, p. 19) “a criança é um ser dinâmico; para ela, arte é uma comunicação do pensamento. Vê o mundo de forma diferente daquela como o representa e, enquanto desenvolve sua expressão, muda". Pode-se então afirmar que a arte infantil é o meio pelo qual a criança cria e retrata sua imaginação. Mobiliza para isso elementos visuais por meio de seu gesto gráfico como exercício de sensibilidade, sentindo-se mais segura para se expressar e explicitar suas necessidades afetivas, emocionais e sociais.

A arte infantil em Marabá tem uma particularidade: ela marca a personalidade da criança, já que revela o seu conteúdo diário com a comunidade, enfatizando o seu eu, como se observa no desenho da figura 03. A criança caracteriza-se pela sua expressividade pessoal, cuja representação equivale à exaltação da família. 
Figura 03. Desenho da família. Caracterização particular da família de um aluno (8 anos) da cidade de Marabá.

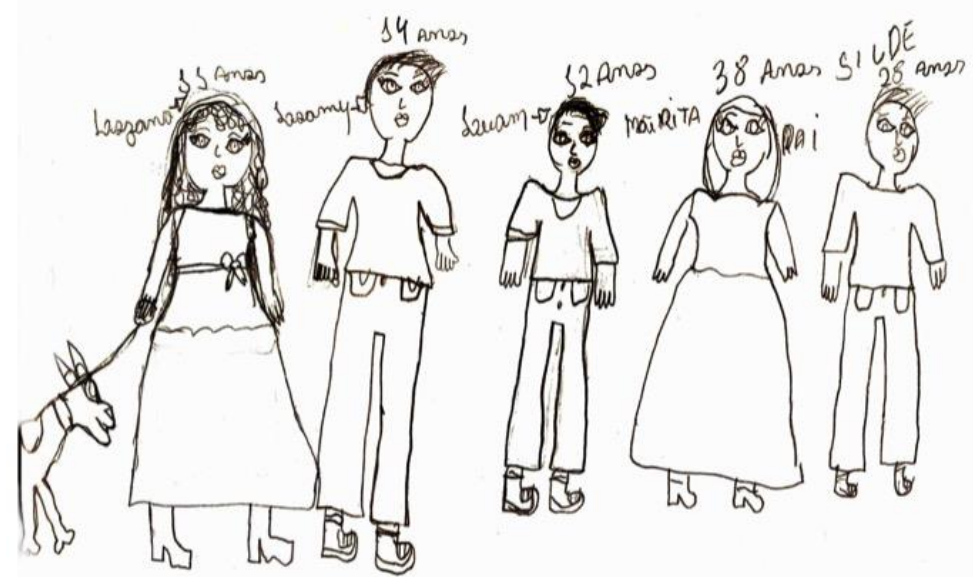

Fonte: Laboratório de Expressão Plástica do Projeto de Pesquisa Racionalidade Estética: estudo do processo de criação artística de criança no município de Marabá.

O desenho apresentado nessa figura (03) é um dos registros e reflexos da representação da família, em que o que está em questão é o modo como ela concebe um esquematismo para poder instituir elementos da sua ambiência sociocultural e afetiva em relação com a cidade de Marabá. Representa como parte de sua experiência com o esquema da figura humana, referindo-se ao cotidiano em que vive e estabelece vínculos com as pessoas que fazem parte da vida dela. Nessa representação gráfica espontânea, a imaginação é livre, os elementos que caracterizam-na como primordiais são índice do avanço de sua consciência, compreensão e percepção refinada de como ver o mundo.

Além da construção da figura humana, a criança marabaense enfatiza no desenho a iconografia do seu repertório social subjacente, elaborando situações que revelam a percepção de sua comunidade em constante diálogo estético com ela. Sua produção artística é cheia de intencionalidade que surge do seu repertório cultural, pois como parte de sua vida mostra situações de suas experiências vividas, afetivas, emocionais, sociais e estéticas. Retrata expressões que se tornam reveladoras da sua forma de pensar sobre algo que faz parte do seu cotidiano. Isso é perceptível em muitas crianças, já que ao retratarem algo em sua arte, remetem-se quase sempre à revelação dos sujeitos que fazem parte da vida dela, seja de um ponto de vista bom ou ruim, é o caso da figura 04. 
Figura 04 - A criança (9 anos) envolve-se com a ideia de preservação da natureza e percebe que a autoridade policial reprime o corte da árvore.

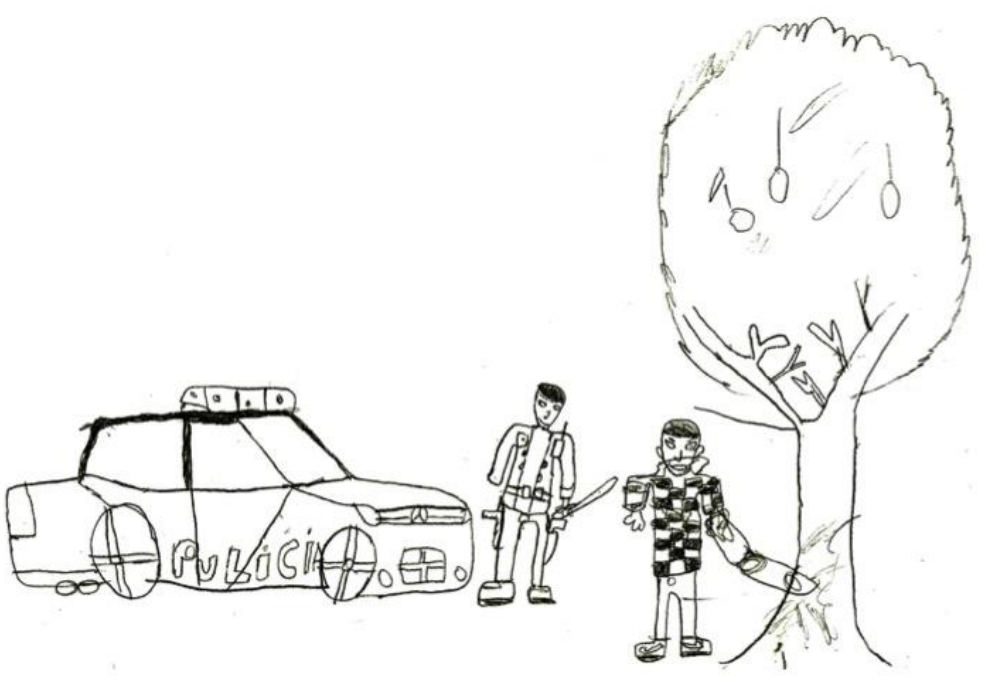

Fonte: Laboratório de Expressão Plástica do Projeto de Pesquisa Racionalidade Estética: estudo do processo de criação artística de criança no município de Marabá.

A arte da criança da periferia urbana de Marabá alcança uma dimensão que não se descola do meio social por estar na fronteira dos temas polêmicos e de pertencimento das famílias de migrantes. Transmite a sensação de fuga para a libertação de sentimentos e espontaneidade, e, ao mesmo tempo, reprimida, direta e indiretamente, pelos recursos da mídia e pelas pessoas do convívio familiar, também da escola e de outros espaços culturais que ela participa.

As interferências (da mídia, do adulto e instituições) têm sido um dos aspectos notórios na arte da criança de periferia no município marabaense. É nítida esta influência, já que é possível identificar o simbolismo fluente nas marcas de sua criação. É interessante perceber as questões indicativas referentes aos repertórios culturais e sociais, já mencionados anteriormente, pois estão sendo projetadas pelas crianças em sua arte. Revelam de certa forma, relações ligadas à formação humana, de identidade e personalidade, assim como impulsionam a expressão dos sentimentos e de compreensão do meio, no qual elas convivem.

A imaginação criadora da criança marabaense está cada vez mais se afunilando numa disseminação da inculcação e imposição de informações a certos valores culturais 
acelerados para o seu desenvolvimento (emocional, intelectual, físico, perceptual, social, estético e criador). A autonomia do processo criador confronta a criança com o desafio de extrair sentidos e atribuir significados a partir da sua realidade imediata, inserindo-a no espaço de maneira provocativa, a fim de lhe possibilitar as escolhas que deverá fazer: “ninguém cria do nada e muito menos para nada. Criar é sempre complexificar, coordenar, combinar de outros modos a partir de uma provocação" (RICHTER, 2008, p. 65). Mesmo que ainda não pertença à noção do que seja o desenhar para a criança, ela já o faz, manipula, explora e transforma o seu mundo com base na imaginação e na criação.

O material artístico da criança de periferia urbana marabaense atende a premissa das oportunidades e do conhecer, visto que amplia e explora as possibilidades de projeção das ideias em que os sentimentos na arte de fazer imagens são o esquematismo mais apropriado da experiência estética vivida. Portanto, a criança, muitas vezes, revela prazer na escolha e na seleção do material, como também no modo que deseja usá-lo na elaboração, expressão e criação de formas visuais. Nesse sentido, o adulto tem papel fundamental, conduzindo e operando a oportunidade da criação artística da criança, pois é ele quem irá organizar e disponibilizar os recursos materiais num dado momento da necessidade espontânea da criança.

\subsection{Esquemas gráficos aplicados à representação estética da família}

A arte infantil da periferia urbana em Marabá é resultante de uma prática histórica do fazer artístico visual que reflete a realidade mediada do ambiente cultural onde a criança vive. O desenho passa a ser uma necessidade própria da infância, uma vez que é o grafismo a sua linguagem poética, que vai se construindo à medida que a meninada experimenta situações. A criança então encontra esquemas gráficos para representar os sentimentos, emoções, desejos e se relacionar com outras crianças e adultos. Aliás, é uma forma de comunicação e expressão. Daí, se diz que o grafismo é o meio pelo qual a criança, da periferia estética de Marabá, revela-se em expressões artísticas e visão ampliada de mundo.

Um grupo de vinte e cinco (25) crianças, na faixa etária de 8 a 12 anos, foram reunidas em uma escola da periferia urbana municipal, a fim de participarem de um 
laboratório de expressão plástica que teve como base o desenho. Partiu-se da premissa de Derdyk (1990, p. 100) de que "qualquer pretexto gráfico é alvo de um campo de representações", uma vez que a criança já tem um repertório visual formado pelo conjunto de experiências vividas no cotidiano da periferia urbana com todos os grupos socais do seu meio.

A experiência do laboratório na periferia revelou-se significativa, pois a questão fundamental se articulava por meio de uma elaboração mental e intelectual, emocional e perceptual, numa dinâmica operativa de mover os sentidos num conjunto de atividades realizadas com as crianças. Além disso, percebeu-se um diálogo estético em sintonia com a problemática estabelecida no e do contexto ambiental, imersa na percepção de mundo das crianças e no conhecimento delas acerca de suas realidades. Identificou-se haver uma forte influência da comunidade sobre a consciência estética infantil na esfera do sensível, do material, do intelectual e mental no que diz respeito aos repertórios inculcados por meio da sociedade e da família.

A partir de uma abordagem heurística da ação realizada no laboratório de expressão plástica, como estudo de caso, experimentaram-se possibilidades de o desenho ser uma criação coletiva e ao mesmo tempo individualizada, possível de poder ser uma representação esquemática capaz de transformar a ação corporal da criança em expressão. Exploraram-se apenas alguns aspectos da representação gráfica, cujo tema foi “A Família”. O desenho conforme define Frange (1995), passou do ato de inquirição ao experimento, abrindo possibilidades, envolvimento de ideias; um meio por onde se explicita a percepção individual de um mundo que habita dentro dos interstícios da mente do ser.

Assim, pode-se pensar na razão da existência do desenho da criança na periferia urbana. Fundamentalmente, existem três teorias que podem explicar o desenvolvimento deste desenho: a concepção conceitualista, a perceptualista e a representacional, conforme classificação teorizada por Frange (1995). A primeira defende a vertente de que as crianças desenham o que elas sabem; isso implica dizer que a cognição e a inteligência são os suportes da elaboração do grafismo infantil. Por outro lado, considera-se que é somente com a maturidade que as crianças irão significar o que sabem fazer. Isso resulta 
em afirmar que o desenho é um sistema simbólico universal e é independente da fala e/ou das convenções culturais.

A teoria perceptualista parte da hipótese de que o "[...] desenho das crianças se desenvolve ou depende de seus esforços de desenhar o que vêem" (FRANGE, 1995, p. 268). Implica conceitos, pensamentos e intuições, já que consiste não somente na imagem que chega aos olhos das crianças: é o desafio delas transformarem aquilo que veem tridimensionalmente em bidimensional. Essa qualidade visual do desenho infantil, diz Arnheim (1980), é única e diferente porque a criança apreende as características formais que compõem as coisas e não o conceito. Por conseguinte, o desenho, nessa teoria, estabelece-se entre a percepção de efeito - guardar na memória visual as características do desenho que a criança vem observando há dias - e percepção da forma - a criança inventa um esquema para configurar uma representação gráfica, mas isso pode comprometer a sua espontaneidade.

Sob o ponto de vista da teoria representacional, o processo do desenho se forma a partir da elaboração mental denominada de esquema ou conceito. A criança é capaz de adotar um esquema de outro desenho já realizado com a mesma temática (ou não), mediante duas suposições: se se sentir insegura emprestará um esquema pronto, ou se for tutorada para aprender a construir um esquema, o adotará provisoriamente e, então, inventará o seu próprio. Gombrich (1986) mostra que historicamente este último vem ocorrendo. Ao emprestar provisoriamente um esquema para a sua representação gráfica, a criança, passo a passo vai se livrando do esquema rígido de desenhar e adquire uma forma particular de representação visual.

O desenho como ato de aprendizagem nessa pesquisa passou a ser a central preocupação, em virtude de ele indicar um momento em que a criança se apropria de um esquema de estereotipia para, assim, representar a imagem no papel. O desenho com esquema de estereótipo é caracterizado por apresentar um modelo padrão de representação visual não pertencente ao desenho próprio da criança. Quando a criança se entrega a esta schemata - rejeição da beleza e adoção do ornamento abstração -, ela passa a copiar e recopiar uma imagem até assimilar o esquema de uma matriz que se dará ao seu pensamento como um clichê, que será reproduzido continuamente nas representações gráficas infantis. Isso é o que se denomina de desenhos estereotipados. 
Esses desenhos feitos a partir de clichês estereotipados esvaziam a expressão artística, o repertório torna-se viciado pelos estereótipos das formas visuais concebidos socialmente por meio da escola, da família e da comunidade. A escola, diz Vianna (1994), é o lugar ideal para se socializar a schemata do estereótipo, já que é lá que se processa com exaustão a aprendizagem das imagens de fácil elaboração, empobrecendo a percepção e inibindo a imaginação infantil. Gombrich (1986) mostra que esse processo concebido pela matriz mental, que promove o estereótipo, produz uma simplificação da forma visual e enrijece a expressão espontânea da criança, que aos poucos vai se subordinando aos ditames dos esquemas prontos, adaptando-se à forma de reproduzir e a não mais criar.

Emerge, então, a seguinte discussão: dada à criança a possibilidade de se expressar livremente, sob a mediação de um tema, neste caso a família, mesmo assim ela frequentemente irá se confrontar com a estética do estereótipo como um problema da tradição através da cópia.

A percepção de mundo das crianças na periferia urbana deu sentido a momentos importantes do diálogo estético com o tema família. Primeiramente, buscou-se a expressão livre das crianças para promover o deslocamento das ideias num desafio esquemático sobre o tema; tendo que superar a estética do estereótipo com o intuito de pensar num modo de desenhar sem o recurso da schemata do estereótipo como modelo já pré-concebido socialmente. Com este desafio pretendeu-se dar às crianças uma ambiência propícia de brincar com o ato de desenhar, de imaginar e usar linhas no espaço do papel de modo mais livre, destacando o processo criativo, o envolvimento afetivo, a segurança no modo do ato de fabricar o desenho como identidade única que sai do seu pensamento e se cristaliza em uma imagem que traduz uma ideia, uma emoção.

O desenho intrinsecamente se coloca num diálogo frente ao inusitado e ao inesperado. Criam-se situações que se confrontam mediante o exercício do ato de realizar e do executivo, no qual o experimental da liberdade é dado como premissa da situação surgida, a partir daí a capacidade de inventar algo é o impulso lúdico necessário para imprimir imaginação, aquilo que vai além da realidade. É o caso de família com o Transforme Bambobee (um robô alienígena que se transforma em carro). Observe a narrativa visual (figura 05): a família da criança é composta de quatro pessoas - mãe, ela 
mesma, pai, irmãozinho e o Robô. O desenho é uma representação que, tem uma schemata própria da idade da criança, traz os membros familiares em uma linha de base, com um esquema de figura humana que se destaca ao centro do papel, um homem ladeado por três pessoas e um robô.

Figura 05. A família com o robô. Arte infantil de um menino de 9 anos. Ele ilustra sua imaginação sobre a sua família a partir do tema cotidiano.
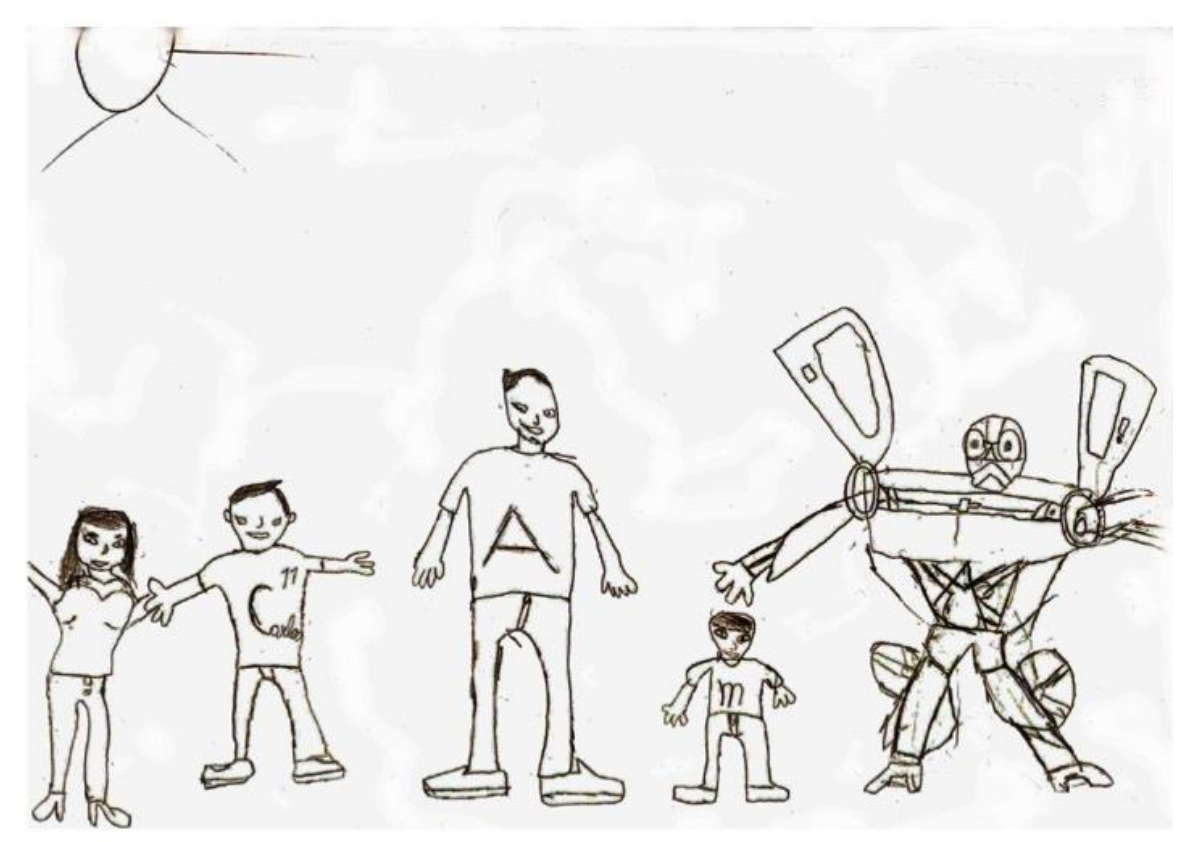

Fonte: Laboratório de Expressão Plástica do Projeto de Pesquisa Racionalidade Estética: estudo do processo de criação artística de criança no município de Marabá.

$\mathrm{Na}$ imaginação da criança está o aspecto fundamental da sua percepção sobre o significado da família, enfatizando elementos importantes na sua consciência do tema cotidiano e do seu repertório lúdico.

Para Frange (1995, p. 322), “a arte é campo no qual os fenômenos se dão, é um campo de incertezas, que contém como dimensão o caos; é uma incerteza desejável de obras abertas"; no caso desta schemata sobre a família (figura 05), a abertura caracteriza a expressão cotidiana da criança, tributo este ao diálogo com o pertencimento da comunidade em que mora e de seus atores envolvidos e de uma referência à indústria cultural do brinquedo e do filme Transformers. 
Apesar de a arte exigir sempre uma dose de liberdade, de decisão e de interpretação, as escolhas quase sempre recaem no repertório instituído pela comunidade: os conteúdos são expressivos e conduzem a criança a perceber o mundo a partir de sua experiência coletiva, do seu contexto cultural. É assim que se revelam, nestes desenhos de três crianças, sobre suas famílias (ver figura 06).

Figura 06 - Três schematas de famílias. São desenhos de crianças diferentes, mas que usam o estereótipo como recurso para suprir suas dificuldades de expressão.

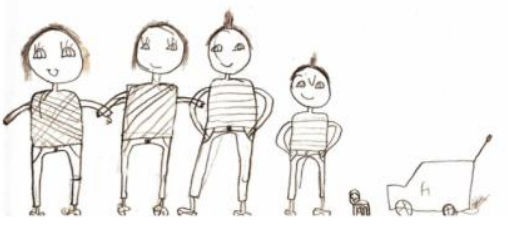

Família 01

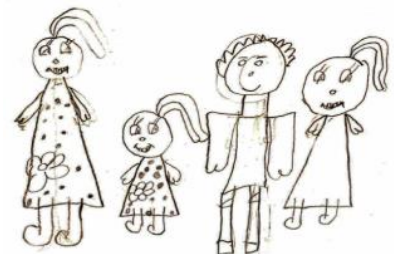

Família 02

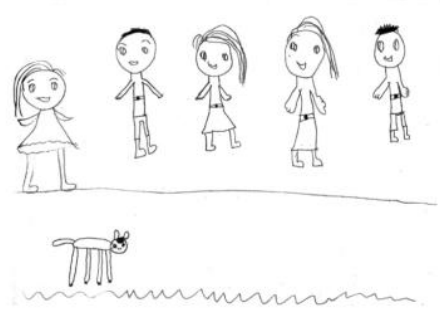

Família 03

Fonte: Laboratório de Expressão Plástica do Projeto de Pesquisa Racionalidade Estética: estudo do processo de criação artística de criança no município de Marabá.

A família 01 está alinhada na base, estruturando o desenho, e todas as figuras estão unidas pelos membros superiores, com exceção da figura menor que está levemente distanciada do grupo e próxima de seus brinquedos. A criança diferencia graficamente o sexo pela construção dos olhos (as femininas possuem cílios e as masculinas não), já que as figuras possuem os mesmo esquemas (as femininas de braços abertos e de blusas com linhas diagonais; e as masculinas com as mãos no bolso e linhas horizontais nas camisetas; ambas de calças compridas). As construções das figuras constituem aspectos que remetem à teorização de Arnheim (1980); ele diz que a criança cria suas representações, destacando a diferença entre o reconhecimento e a imitação. A criança é capaz de reconhecer seus pares familiares e identificação de pormenores que os representam graficamente, destacando as diferenças que são conceituais, mas que acabam se revelando percepções formais, principalmente, pelo fato de haver uma representação da percepção de efeito. 
A construção dos olhos das figuras das famílias 01 e 02 demonstram que as crianças tiveram dificuldades de representá-los. Daí, elas apelaram para o esquema mais fácil, o do estereótipo. Nessa elaboração, tomam emprestada a esquemática do clichê Pi Ching - tipógrafo que inventou o processo de impressão gráfica por meio de elaboração de clichês no ano de 1.040 na China -, e realizam dois tipos de percepção de forma: os olhos recebem a forma de meia lua, a pupila é colocada no canto (esquerdo ou direito) e depois faz-se os cílios com três traços na parte superior da meia lua, conforme figura 07 (VIANNA, 1994).

Figura 07 - Os desenhos mostram como as crianças se apropriaram do schemata do estereótipo para representar os olhos das figuras.
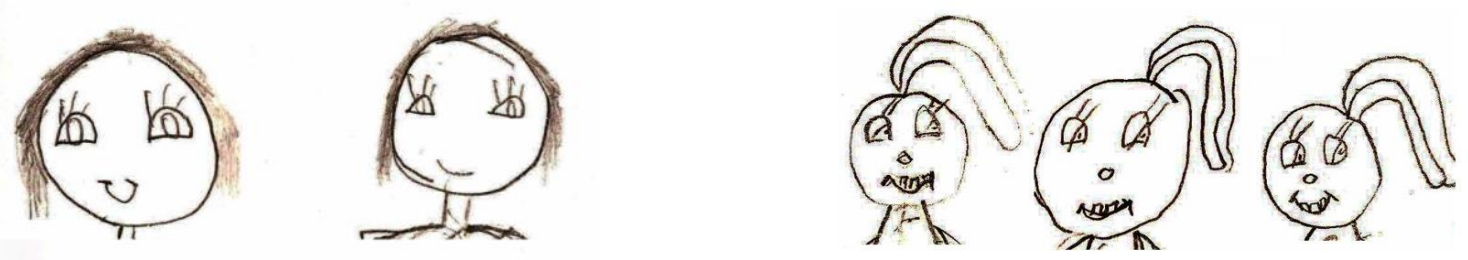

Fonte: Laboratório de Expressão Plástica do Projeto de Pesquisa Racionalidade Estética: estudo do processo de criação artística de criança no município de Marabá.

A família 02 traz como base uma configuração geométrica para a construção das figuras: triangular feminina e retangular masculina. Parte da premissa conceitualista, pelo fato de desenhar expressando o que sabe da figura: simetria do corpo com dois braços, duas pernas, dois olhos, a vista frontal caracterizada pelo esquema geométrico - círculo para a cabeça, triângulo e/ou retângulo para o corpo. Este esquema é o conceito que a criança tem de um objeto e representa o conhecimento ativo dele, conforme Lowenfeld e Brittian (1970). É resultante de uma exaustiva repetição pela criança.

Convém, no entanto, lembrar que há uma diferença entre um esquema conceitual na aprendizagem da criança, considerada pela teoria conceitualista, como esquema flexível, já que muda de acordo com a maturação da criança, e aquela schemata estereotipada, que permanece inalterada. Porém, é bom não esquecer que os desenhos 
de duas crianças não são idênticos, tampouco se existirem dois esquemas análogos, pois depende muito da personalidade e do grau de envolvimento das crianças com o conceito que estão trabalhando, até porque, pode-se dizer que existe um esquema humano de representação do conceito de uma figura que a criança criou observando as pessoas da periferia urbana em Marabá, mesmo sabendo que o esquema para representar as personagens de sua família pode variar de um dia para o outro.

Sem dúvida, à medida que a criança desenvolve o símbolo homem ou mulher, continuamente repetido na sua representação gráfica, é porque ela adquiriu o poder da representação formal destas figuras na ordem do conceito. Daí ela se interessar pelos detalhes e incluir pormenores, ocasionalmente, na imagem de seu esquema.

No caso da família 02, na figura 06, a criança adiciona nas roupas femininas um esquema décor floral com pontinhos distribuídos na superfície do triângulo e, na cabeça das formas que representa a mulher, há um esquema para o cabelo longo. Braços e pernas das figuras são elaborações que ainda não estão maduras; a criança empresta da schemata estereotipada um modo simples para caracterizá-los.

Na família 03, as figuras são representadas em uma estrutura em que a criança descobre que existe um espaço entre as linhas de base dupla que ela desenha. Isso tornase significativo, visto que o plano passa a ser o espaço da expressão simbólica do conceito de linha. Logo, na primeira linha embaixo, sinuosa, está um animal, com seus detalhes - olhos, unhas, pernas longas, cauda e orelhas. Na linha acima, estão figuras esquemáticas de homens e mulheres, representadas geometricamente: círculos para a cabeça, triângulo para os corpos femininos e retângulos para os masculinos.

A linha de base como conceito de chão deixa de existir, pois agora a criança tem um desafio: pensar o espaço tridimensional e traduzi-lo em um desenho bidimensional. Para a percepção de efeito, obviamente, isso tem um significado importante, pois marca o princípio da diferenciação, como princípio gestaltiano da simplicidade. Quer dizer, a simples redução da percepção da forma em usar as linhas para representar os planos, implica em indiferenciar a profundidade existente entre o animal e a família (figura 03).

Por outro lado, afirma Arnheim (1980, p. 171): “[...] até que um aspecto visual se torne diferenciação, a série total de suas possibilidades será representada pela 
estruturalmente mais simples entre elas". Logo, a criança que desenhou a família 03 articulou a ideia de profundidade. Ela usou um esquema simples de linhas em paralelo para sistematizar a sua solução para o problema mental de diferenciação linear do espaço, a fim de poder traduzir o tridimensional em bidimensional.

Mediante o coletivo temático, imbuído da comunicação comunitária, as crianças da periferia urbana em Marabá estabelecem ações, nas quais se desdobram para pensar o meio ambiente como algo frágil e precioso. Concomitante a isso, é fundamental ver o desenrolar das performances visuais das crianças da periferia urbana. Explicita-se essa questão com o argumento de Derdyk (1990, p. 116), de que ela apresenta uma caracterização importante: “Observar uma criança desenhando, acompanhar o processo de construção na plenitude de sua ação, pode nos devolver um vínculo mais profundo do que aquele que o ato de desenhar promove dentro de quem desenha". Isso vai além do simples ato de estereotipias, insegurança, espontaneidade, racionalidade e ocupação de espaço visual.

Gombrich (1986) diz que o desenho é uma concepção de esquemas que vai pouco a pouco sendo elaborada pela mente da criança. Esta desenha o que sabe e vê através de seus significados. Em todo caso, a família representada na arte da criança da periferia urbana de Marabá é uma formulação simbolizada dada pela imaginação, a fim de representar a figura como algo que expressa o sentimento das pessoas que são retratadas e não algo como se fosse o semelhante. Este diálogo estético situa a morfologia humana em que a gestualidade corporal é captada como recurso de uma expressividade latente. É simplesmente um modo de aprendizagem enquanto elabora o mundo dentro se si mediado pelo mundo do seu ambiente de periferia.

O laboratório de expressão plástica realizado na periferia urbana de Marabá pôde consolidar um acervo gráfico de desenhos realizados por crianças em situação de violência simbólica. Estes desenhos são reveladores, pois podem indicar um conjunto de fatores concernentes ao diálogo estético no sistema da estética amazônica e periférica, cuja poética de arte infantil se vislumbra e é propícia para o entendimento da realidade do homem que trafega e se enraíza na região. 


\section{Dinâmica sociocultural amazônica e a arte infantil no ambiente cotidiano}

No âmbito da cultura da criança na periferia urbana de Marabá, esta pesquisa desenvolve reflexões críticas sobre o processo educativo estético de crianças. Daí ressaltar o estado de risco social, mediante a subordinação de uma quantidade imensa de violência física, social e simbólica na periferia urbana interferindo na educação dentro e fora da escola.

No âmbito da crítica social, educativa e dos conhecimentos sobre a infância, podese dizer que há uma necessidade de se ter melhor compreensão sobre a capacidade de esquematizar da criança, relacionada à percepção de mundo e dos conceitos adquiridos na convivência com a periferia urbana. Estabelecem-se correlações significativas entre os esquemas impostos pela sociedade capitalista mediante os valores de consumo que refletem a diversidade de compreensão da criança e o confronto da própria situação em que ela vive na família. Nesta conjuntura, coloca-se em questão a cultura estética de periferia e seus desdobramentos na educação de crianças diante de uma estrutura sóciopolítica e educacional impositiva, desafiadora do conceito contemporâneo de humanidade.

As bases fundantes e relevantes deste estudo satisfazem as condições ontológicas de promover reflexão sobre o "ser humano", frente à concepção ampla e de totalidade da humanidade. Conforme críticas já consolidadas por Horkheimer e Adorno (1985, p. 82), há uma situação de subordinação que deve ser repensada, tal qual o "funcionamento inconsciente do mecanismo intelectual que já estrutura a percepção em correspondência com o entendimento". Isso inclui outras condições de importância no presente estudo, já que o indivíduo afetado pela cultura hegemônica e que, no conjunto das representações simbólicas, emergem aspectos relacionados com a classe, etnia, lugar de moradia e a natureza de ser criança em uma cidade de fronteira, o que implica vencer as formas de exploração, opressão social e dominação política.

Há, sobretudo, um problema que deve ser enfrentado na diretriz da pesquisa em ciência da educação, que é a comunidade dos fatos imediatos, numa proporção tal que reflete a situação no campo das ciências humanas tipicamente como dado socioeconômico e da cultura na contemporaneidade: a violência. Ressalta-se ainda que 
tanto este aspecto como aquele surgem da percepção, já que o que está em jogo no avanço da ciência, no âmbito socioeducativo e cultural, é a constituição de um mundo simbólico de periferia que influi nas condições materiais e econômicas, determinando a consciência, os valores humanos e as formas de comportamento. Além do mais, representa a existência de hierarquias sociais e intelectuais que invadem a racionalidade da criança de diversos modos e influi na sua formação cidadã - a criança na periferia não é reconhecida (em sua maioria) por seu próprio valor e infância.

Aliás, no âmbito dos discursos relativos à violência infantil há uma dificuldade na região de se tomar partido pelos direitos da criança. E por se tratar de direitos, isso pode ser considerado não científico, fato que a cientificidade do caso pode trilhar novos caminhos. Em parte, considerando que tanto em ciências naturais como em humanas há o papel incomensurável da filosofia, esta, enquanto discurso articulado e rigoroso, sustenta as rupturas epistemológicas e, nesse caso, lançam-se bases da interdisciplinaridade. Se existe uma periferia da infância e se esta é determinada pelos valores sociais do pensamento hegemônico, alienante e de controle do conhecimento e dos bens culturais daqueles que habitam a periferia da cidade é porque há uma demanda indelével que é preciso conhecer, descortinar o véu do poder dos conceitos instituídos pela mecânica da ciência positivista.

E certamente que conhecer a realidade educativa e cidadã da periferia é fazer ciência de modo ampliado no contexto cultural e social. Porém, nada mais contraditório do que a acessibilidade relacionada à forma de receber informação do mundo preparada pelos adultos, codificada, criptografada a ponto de impossibilitar qualquer unidade do pensamento dirigido pela razão e que de fato irá atingir a formação estética da criança.

Esta pesquisa, então, desenha sua importância para além da esfera da realidade imediata, pois como já foi dito, a epistemologia que se rompe tem marcas na esfera teórica fundamentada com os princípios filosóficos e sociais sobre o conceito de violência compreendido. Tal premissa fundamental traz relevantes estudos críticos com o criticismo kantiano, sobretudo, no que diz respeito ao entendimento do esquematismo, já que este não tem despertado interesse da comunidade científica nacional em desdobrá-lo com o conceito de educação estética em Schiller (2002). 
Mediante este fato, a ênfase na educação dos sentidos e no estudo político do impulso criador evoca o conceito de cultura de periferia como princípio: educação como cultura e cultura como educação, baseado nos propostos de Brandão (2007). É, por outro lado, compreender o processo de criação que envolve as matrizes culturais norteadoras do pensamento da criança, dando destaque ao caráter humano do ser criativo - mesmo que este tenha sido subordinado às questões que preestabelecem certos significados (OSTROWER, 2009).

Este estudo ao se remeter à forma estética, sem dúvida que está a implicar na educação. Tal gérmen encontra-se filosoficamente enunciado na síntese do esquematismo marcusiano que demanda dimensão estética (MARCUSE, 1977). Isto posto, representa mais uma forma relevante de contribuição para o avanço das ciências humanas e educacionais: a noção de subjetividade empertigada nos aspectos da realidade em que a criança vive e convive em torno da violência amplamente massificada. Refere-se ainda ao modo objetivo de um mundo envolvente que se revela às condições de um esquematismo existente na periferia da cidade de Marabá, posto que de tanto a criança se martirizar, na vida violentada e violenta que ela leva, em muitos casos, quando constrangida, não tem mais perspectiva de superação.

Destarte, pensa-se que a criança que sofreu violência simbólica, social e física tem sua experiência afetada por um acontecimento radical com a forma estética no mundo objetivo em que vive, mas também que reflete de algum modo um esquematismo que interfere no amadurecimento e na estrutura subjetiva da criança quando se dirige na constituição com a "forma viva", com o significado da beleza por meio do elemento lúdico que ainda sobrevive em seu esquema de brincar.

Assim, concebe-se a ciência do conhecer a criança, pois têm relevância as definições que elucidam a experiência estética infantil como um modo de definir sua cultura educacional, nas condições dadas pela vida na periferia da cidade de Marabá, mediada pelas contradições da sociedade atual. Convertendo a relação da criança com a forma de expressão estética num processo libertador, por meio da criatividade e imaginação, o que se aproxima da arte, da ciência, da estética e da tecnologia de

\footnotetext{
2 Para Schiller (2002) a "forma viva" representa a unidade do estético que se materializa por meio da criatividade, assume um significado que pode falar ao outro a qualquer momento de recepção estética.
} 
construção de artefatos que suscitam objetivar o aspecto lúdico da produção poética da criança.

Logo, há também que considerar para a maior importância deste estudo científico, o conhecimento da realidade infantil em meio ao mundo da violência e a autonomia da criança nas condições heterônomas dadas, pela capacidade de esquematização e funcionalidade dos esquemas de caráter nitidamente ideológico e abertamente opressivo, engessadores da emancipação infantil, criando-se meios de acreditar que são os estereótipos a principal estratégia discursiva do mercado.

\section{Considerações finais}

O que se rompe nesse processo de rastreio interdisciplinar, abre-se como fresta de atenção na fronteira da produção artística infantil, referente a um primeiro impacto de interesse social no formato da educação intercultural na territorialidade Amazônica. Nessa perspectiva, a intersticialidade presente no papel da criatividade é o nicho da guarda da produção da arte da criança na periferia urbana de Marabá. Ampliam-se também os anseios esquematizados provenientes da expressividade individual de uma estética tipicamente incorporada por meninas e meninos amazônidas. Sobretudo, porque promover qualidade de vida, tratar de uma estética livre das amarras que os constrangimentos sociais têm promovido durante décadas nas sociedades do Sul e Sudeste do Pará são desinências do conflito da infância na América Latina.

Faz-se, sobretudo, um levantamento significativo da produção artística das crianças amazônidas envolvidas nesta pesquisa, concernentes aos territórios da periferia urbana e, por conseguinte, cria-se uma cartografia da memória educacional e estética das crianças na periferia da cidade de Marabá. Esclarecendo ainda que o significado da arte e da educação sistêmica e a produção poética da criança, mostram-se perfilados pelo deslocamento, mediante o processo educativo estético por via da violência característica que medeia a natureza dos esquemas concebidos pela criança. Não é à toa que o padrão instituído no âmbito social da periferia urbana tem sido ainda dado pelas condições instituídas como vida material em constante processo de transformação social, política e espiritual. Logo, tais padrões instituídos determinam as condições econômicas e influem 
na consciência, nos valores e na forma de comportamento existentes na periferia urbana da cidade.

Através desse contexto e com base no desenvolvimento regional amazônico, toma-se a forma da visualidade infantil como fronteira que hospeda problemas amazônicos, cuja correspondência dinâmica do sistema de produção estética e poética infantil implica ações educativas. Resultante dessa necessidade há a teorização, as críticas de cunho social - com o intuito de empreender um processo de construção do pensamento coletivo -, e crítico centrado na compreensão da situação real das crianças da periferia urbana em questão.

Outra consideração refere-se ao movimento resultante do impacto operado, ao revelar a realidade urbana da periferia, emergente da articulação entre o espaço de análise e a reflexão crítica sobre a situação das crianças no que diz respeito às políticas públicas orientadas aos problemas e práticas sociais das quais é possível derivar aprendizagens para a suposta marcha em diferentes contextos da periferia urbana em Marabá. Enfim, encontram-se contribuições significativas como a difusão desta orientada para a produção de projetos de aprendizagem circunstanciadas. 


\section{Referências}

ADORNO, Theodor W. Teoria estética. Tradução Artur Morão. Lisboa: Edições 70, 2006.

ARNHEIM, Rodolf. Arte e percepção visual: uma psicologia da visão criadora, Trad. Ivonne Terezinha de Faria. São Paulo: Pioneira; USP, 1980.

BECKER, B. Dinâmica Urbana na Amazônia. In: DINIZ, C. C; LEMOS, M.B. (Org.). Economia e Território. Minas Gerais: UFMG, 2005. p. 401-428.

BRANDÃO, Carlos Rodrigues. O que é educação. São Paulo: Brasiliense, 2007.

DERDYK, Edith. O Desenho da Figura Humana. São Paulo: Scipione, 1990.

OSTROWER, Fayga. Criatividade e processos de criação. 24. Ed. Petrópolis: Vozes, 2009.

FRANGE, Lucimar Belo P. Por que se esconde a violeta? isso não é uma concepção de desenho, nem pós-moderna, nem tautológica. São Paulo: ANNABLUME, 1995.

FREITAS, Verlane. Adorno \& a arte contemporânea. Rio de Janeiro: Jorge Zahar, 2003.

GOMBRICH, Ernest H. Arte e Ilusão: um estudo da psicologia da representação pictórica. São Paulo: Martins Fontes, 1986.

HEYWOOD, Collin. Uma história da infância. Tradução Roberto Cataldo Costa. Porto Alegre: Artemed, 2004.

HOKHEIMER, Max; Adorno, Theodor W. Dialética do esclarecimento: fragmentos filosoficos. São Paulo: Zahar, 1985.

HOKHEIMER, Max. Eclipse da razão. Tradução Sebastião Uchoa Leite. São Paulo: Centauro, 2002.

LOWENFELD, Victor. A criança e sua arte. Trad. Miguel Maillet. São Paulo: Mestre Jou, 1977.

LOWENFELD, Victor. \& BRITTIAN, W. L. Desenvolvimento da capacidade criadora. Trad. Álvaro Cabral. São Paulo: Metre Jou, 1970.

MARCUSE, Hebert. A dimensão estética. Trad. Maria Elisabete Costa. Lisboa, Portugal: Edições 70 \& Martins Fontes, 1977.

POSTMAN, Niel. O desaparecimento da infância. Trad. Suzana Menescal de Alencar Carvalho e José Laurênio de Melo. Rio de Janeiro: Graphia, 1999.

RICHTER, San. Criança e pintura: ação e paixão do conhecer. 3.ed. Porto Alegre: Mediação, 2008. 
SANTOS-FILHO, Alexandre. S. Esquematismo, expropriação e emancipação. In: SANTOSFILHO, Alexandre S. A dimensão estética do brinquedo. Rio de Janeiro: Marsupial, 2016. p. 71-102.

SCHILLER, Friedrich. A educação estética do homem: numa série de cartas. Trad. Roberto Schwarz e Márcio Suzuki. São Paulo: Iluminúrias, 2002.

VIANNA, Maria Leticia. Desenhos estereotipados: considerados ervas daninhas o que podemos fazer com eles? Revista do Professor. Porto Alegre: v. 10, n. 38, p.23-7, abr./jun., 1994.

WILSON, Brent; WILSON, Mary. Uma visão iconoclasta das fontes de imagem nos desenhos de crianças. In: BARBOSA, Ana Mae. Arte - educação: leitura no subsolo. São Paulo: Cortez, 1997.

Universidade do Estado de Santa Catarina - UDESC Programa de Pós-Graduação em Educação - PPGE Revista Linhas

Volume 19 - Número 40 - Ano 2018 revistalinhas@gmail.com 